\title{
Djevojčice i žene s poremećajem iz spektra autizma
}

\author{
Jasmina Stošić ${ }^{1}$, Matea Begić1, Marina Soldan² \\ 1 Edukacijsko-rehabilitacijski fakultet Sveučilišta u Zagrebu, Zagreb, Hrvatska \\ 2 Agencija za zapošljavanje Smartflex, Zagreb, Hrvatska
}

Sažetak: Poremećaj iz spektra autizma uključuje različitosti i teškoće na području socijalne komunikacije te na području ponašanja, interesa i aktivnosti. lako je smatran dominantno "muškim" poremećajem, novija istraživanja upućuju na to da je broj djevojčica i žena s PSA-om podcijenjen, da kasnije dobivaju dijagnozu i da je potrebno da izražavaju puno više težih simptoma da bi je dobile. U ovom će radu biti prikazana obilježja djevojčica i žena s poremećajem iz spektra autizma u kojima se one razlikuju od dječaka i muškaraca. Prema dosadašnjim istraživanjima, djevojčice i žene izražavaju manje teškoća u socijalnoj komunikaciji, u većoj mjeri upotrebljavaju socijalno maskiranje, češće imaju tipične interese te su kod njih manje prisutna ograničena i repetitivna ponašanja nego u dječaka i muškaraca s poremećajem iz spektra autizma. Potrebno je provesti daljnja istraživanja prevalencije, iskustava žena i djevojčica te njihova različitog izražavanja PSA-a. To će omogućiti bolje prepoznavanje i dijagnostiku, a samim time omogućiti i pravovremeno dobivanje podrške te kreiranje usluga koje su iskrojene prema njihovim specifičnostima.

Ključne riječi: autizam, žene s poremećajem iz spektra autizma, socijalno maskiranje

\section{UVOD}

Poremećaj iz spektra autizma (PSA) ${ }^{1}$ uključuje različitosti i teškoće na području socijalne komunikacije te na području ponašanja, interesa i aktivnosti. Iako i kod tzv. neurotipične populacije nalazimo "autistične" karakteristike i ponašanja, do dijagnoze dolazi kad kvaliteta, intenzitet i zajednička pojavnost tih karakteristika uzrokuju teškoće u svakodnev- nom životu (Lai i sur., 2013). PSA istovremeno prožima i zahvaća više razvojnih područja i može različito utjecati na svako od njih, što rezultira velikom raznolikošću razvojnih profila i ishoda (Cepanec, Šimleša i Stošić, 2015). Poremećaj iz spektra autizma tradicionalno se smatrao predominantno "muškim" poremećajem. Rezultati različitih epidemioloških

\footnotetext{
U okviru ovog rada naizmjence će se koristiti termin osoba s poremećajem iz spektra autizma i termin osoba s autizmom poštujući stav samih osoba o prihvatljivom jeziku koji su izrazile u okviru istraživanja Autism Europe (2016), provedenog u nizu Europskih zemalja.
} 
studija upućivali su na to da je omjer muškaraca i žena 4 do 5 naprama 1 (npr. Fombonne, 2009; Baio, 2018), također se isti omjer navodi i u DSM-5 priručniku (APA, 2013). U nekim istraživanjima u različitim zemljama spominju se i omjeri od 6 do 8.1 naprama 1 (Icasiano, Hewson, Machet, Cooper i Marshall, 2004; Fombonne, 2003, 2005), a s druge strane neka istraživanja upućuju na prevalenciju od 2 naprama 1 (Fombonne, Du Mazaubrun, Cans i Grandjean, 1997). Istraživanja usmjerena na procjenu prevalencije i omjera muškaraca i žena s PSA-om su vrlo heterogena obzirom na karakteristike i veličinu uzorka, istraživački nacrt i kvalitetu. U nastojanju da uzmu u obzir tu heterogenost i ograničenja prijašnjih istraživanja Loomes, Hull i Mandy (2017) su proveli sustavni pregled istraživanja i metaanalizu kako bi se što točnije utvrdio omjer muškaraca i žena s PSA-om. Njihov pregled je uključivao 54 istraživanja iz SAD-a, Kanade, Europe, Azije, Južne Amerike i Australije. Ključno je bilo utvrditi na koji način su odabirani sudionici. Tako su istraživanja podijeljena na ona koja uključuju aktivne i ona koja uključuju pasivne metode odabira sudionika. Aktivne metode uključuju probir uzorka populacije bez obzira na to jesu li sudionici već dijagnosticirani ili primaju određenu uslugu. Za razliku od njih, pasivne metode uključuju u uzorak one kod kojih je već utvrđena dijagnoza PSA ili su primatelji određene usluge. Aktivne metode na taj način omogućavaju obuhvaćanje sudionika koji do sada nisu prepoznati. Također je bilo važno uzeti u obzir i dob sudionika s obzirom na to da se pokazalo kako djevojčice kasnije dobivaju dijagnozu od dječaka (Giarelli i sur., 2010; Begeer i sur., 2013) te bi prema tome kod mlađih sudionika omjer bio veći nego kod starijih. Rezultati metodološki kvalitetnijih istraživanja te onih koji uključuju aktivnu metodu u odabiru sudionika pokazala su da je omjer bliži 3 naprama 1. Općenito su istraživanja koja upotrbljavaju pasivnu meto- du upućivala na veći omjer između dječaka i djevojčica, a ona koja uključuju aktivnu metodu na manji omjer (Loomes i sur., 2017). $\mathrm{Na}$ manji omjer upućuju i istraživanja koja su upotrbljavala samoprocjenu ili procjenu roditelja o "autističnim" značajkama kod svoje djece i ona su pokazala da bi taj omjer mogao biti i 2 naprama 1 (Constantino i Todd, 2003; Constantino, Zhang, Frazier, Abbacchi i Law 2010). Djevojčice također trebaju pokazivati puno više "težih" simptoma, odnosno dodatnih teškoća kao što su intelektualne teškoće ili problemi u ponašanju da bi dobile dijagnozu (Russell, Steer i Golding, 2011). Takvi rezultati mogu upućivati na zaključak da postoji značajan broj djevojčica i žena koje ne dobivaju dijagnozu unatoč tome što izražavaju karakteristike PSA-a te samim time ne dobivaju ni podršku koja im je možda potrebna. Čini se da su žene i njihove specifičnosti bile zanemarivane u okviru istraživanja na području poremećaja iz spektra autizma. Tijekom posljednjeg desetljeća ta situacija se mijenja te dolazimo do novih spoznaja o specifičnostima i različitostima žena s PSA-om.

Cilj ovog rada jest analizirati dostupna istraživanja kako bi se utvrdilo u čemu se djevojčice i žene s autizmom razlikuju od muškaraca, odnosno u kojim obilježjima "odskaču" od uvriježene slike autizma te navesti implikacije tih različitosti na buduća istraživanja i kliničku praksu.

\section{Karakteristike socijalne komunikacije}

Prvi dijagnostički kriterij za poremećaj iz spektra autizma su teškoće u socijalnoj komunikaciji i socijalnoj interakciji čija težina može varirati i koje mogu biti izražene u različitim kontekstima (APA, 2013).

Neka istraživanja su pokazala postojanje sličnosti između dječaka i djevojčica s PSA-om 
Stošić, J., Begić, M., Soldan, M., Djevojčice i žene s poremećajem iz spektra autizma, Klinička psihologija 13 (2020), 1-2, 95-106

u teškoćama razumijevanja jezika, socijalnog konteksta, recipročnih socijalnih interakcija te komunikacije (Koyama, Kamio, Inada i Kurita, 2009; Mandy i sur. 2012). Unatoč osnovnim sličnostima, istraživanja upućuju na to da postoje određene razlike između njih koje više dolaze do izražaja u odrasloj dobi.

Odrasle žene s PSA-om imaju bolje razvijene vještine socijalizacije i komunikacije, te prema Dijagnostičkom protokolu za procjenu autizma (ADOS - Autism Diagnostic Observation Scale) (Lord i sur., 2000), u odrasloj dobi imaju manje teškoća u tim domenama nego što su imale u djetinjstvu (Lai i sur., 2011). Holtmann, Bölte i Poustka (2007) s druge strane navode kako žene s PSA-om u odrasloj dobi mogu biti socijalno nezrele i razviti ovisnost o drugim ljudima.

Djevojčice posjeduju rječnik s više riječi koje opisuju emocije nego dječaci s PSA-om (Kreiser i White, 2013), bolje uče neverbalnu komunikaciju promatranjem, te bolje kognitivno razumiju pravila povezana s prijateljstvima, socijalnim ponašanjem i emocionalnošću (Lai i sur., 2011; Lehnhardt i sur., 2015). Unatoč tome što pokazuju razumijevanje tih pravila kad o njima izvještavaju, u prirodnom kontekstu mogu biti "socijalno zbunjene” jer imaju teškoća u interpretaciji suptilnosti mimike, intonacije glasa i čitanja govora tijela (Kreiser i White, 2013) te nisu sigurne koja socijalna pravila trebaju primijeniti u pojedinim socijalnim situacijama (Bargiela, Steward i Mandy, 2016).

Također se pokazalo da dječaci i muškarci s PSA-om u neposrednoj komunikaciji imaju neprimjereniji izraz lica i više teškoća sa združenom pažnjom (Holtmann i sur., 2007), dok žene pokazuju značajno manje "autističnih" ponašanja (Lai i sur., 2011) i nemaju hiperfokus na područja usta. Ipak, ako ih uspoređujemo s neurotipičnim ženama, žene sa PSA-om su tijekom socijalne interakcije kraće usredotočene na lice osoba (Ketelaars i sur., 2017).
Različitosti postoje i u odnosima s vršnjacima. Djevojčice s PSA-om, jednako kao i dječaci imaju teškoća u grupnim igrama s vršnjacima (Holtmann i sur., 2007) te izvještavaju kako se osjećaju mnogo ugodnije u društvu samo jedne osobe (Bargiela i sur., 2016).

Djevojčice tipičnog razvoja svoje interakcije ostvaruju u manjim i intimnijim skupinama te od interakcije imaju veća očekivanja od dječaka (Maccoby, 1999). Njihova interakcija usmjerena je na međusobni odnos, a ne toliko na situaciju ili temu oko koje se interakcija odvija (Larson i Richards, 1989; Raffaelli i Duckett, 1989) za razliku od djevojčica sa PSAom, kojima odnos nije toliko bitan (Attwood, 2006).

Dean, Harwood i Kasari (2016) su promatrali kako se djevojčice s PSA-om ponašaju sa skupinom djevojčica tipičnog razvoja na školskom igralištu. Zamijetili su da one provode puno više vremena u blizini svojih vršnjakinja od dječaka, ali imaju teškoća u sudjelovanju u aktivnostima koje zahtijevaju socijalno usklađivanje i prilagodbu normama grupe. No, za razliku od dječaka, one će se, u trenutku kada vide da je to moguće, pokušati uključiti u interakciju, a vršnjakinje će ih obavijestiti ako učine neku socijalnu pogrešku (Goodwin, 2006). Unatoč tome što se djevojčice s PSA-om mogu ponašati sramežljivo i povučeno, imat će više prilika za socijalne interakcije i razvijanje prijateljstva (Kreiser i White, 2013). Često imaju jednu prijateljicu koja se zaštitnički ponaša prema njima, svjesna teškoća djevojčice s PSA-om, ali je uvijek poziva u socijalne situacije (Attwood, 2006). Žene s PSA-om neće spontano razviti internalizirane osobne standarde prema kojima bi evaluirale vlastito ponašanje, pa možda neće ni zamijetiti da se ne ponašaju u skladu sa trenutnom socijalnom situacijom ako za to ne dobiju jasnu negativnu povratnu informaciju od okoline (Kreiser i White, 2013). Moguće je da interes za socijalnu okolinu i povratna 
informacija koju dobivaju pridonosi učenju i stjecanju iskustava u socijalnim situacijama te bar djelomično objašnjava bolje vještine socijalne komunikacije u odrasloj dobi o kojima Lai i sur. (2011) izvještavaju. Drugi dio objašnjenja može uključivati kulturne norme i očekivanja vezana za djevojčice i dječake. I djevojčice i dječaci s PSA-om su osjetljivi na očekivanja društva pa se tako i djevojčice i dječaci kada su uključeni u socijalne interakcije, ponašaju u skladu s očekivanjima za osobe njihova spola (Dean i sur., 2016). Tako će "hladno" ponašanje, socijalna neosjetljivost te neka ometajuća ponašanja djevojčica s PSAom biti više osuđivana od strane društva, te neki autori naglašavaju da i zbog toga može doći do internaliziranja problema i imitiranja ponašanja koja se za žene smatraju tipičnima i prihvatljivima (Kreiser i White, 2013).

Povratne informacije i očekivanja okoline mogu imati dobre strane i dovesti do toga da djevojčice uče primjerena ponašanja, no može doći i do negativnog utjecaja. Naime, djevojčice $\mathrm{i}$ žene se u socijalnim situacijama često biraju ponašati pasivno i rezervirano kako bi izbjegle negativne reakcije od vršnjaka ili neku socijalnu grešku (Attwood, 2006; Bargiela i sur., 2016). Isto tako, zbog svega navedenog, mogu biti izuzetno ranjive, te kada dođu u opasnu situaciju, možda se neće znati zaštititi (posebice od seksualnog zlostavljanja) (Bargiela i sur., 2016). S druge strane, kada odaberu ne ponašati se pasivno i "poslušno", nego se nauče ponašati asertivno, teže će odrediti u kojoj situaciji je takvo ponašanje prihvatljivo i povremeno mogu djelovati izuzetno grubo (Bargiela i sur., 2016). U objašnjavanju specifičnosti socijalne komunikacije žena s PSA-om važnu ulogu ima koncept socijalnog maskiranja (engl. social camouflaging) koji će detaljnije biti objašnjen u sljedećem dijelu.

\section{Socijalno maskiranje}

Socijalno maskiranje je odnos između eksternaliziranog i vidljivog ponašanja osobe $u$ socijalnom kontekstu i unutarnjeg stanja osobe, odnosno onoga o čemu nas osoba izvještava o sebi tijekom socijalne situacije (Lai i sur., 2016).

U istraživanju Hull i sur. (2017) izdvojena su dva glavna razloga zbog kojih osobe $s$ PSA-om upotrebljavaju socijalno maskiranje. Jedan od njih je kako bi se povezali sa socijalnom okolinom. U tim situacijama važna je intrinzična motivacija osobe da ispuni pojedine ciljeve, primjerice da ostvari prijateljstvo, te tako kompenzira teškoće u socijalnoj komunikaciji. A drugi razlog je asimilacija, odnosno prilagodba. Ona je izazvana okolinskim čimbenicima koji su osobu potaknuli na određenu vrstu ponašanja. Osobe su i u ovoj situaciji intrinzično motivirane jer žele izbjeći diskriminaciju i odbijanje okoline te zbog toga prikrivaju simptome PSA-om i pokušavaju biti slične ljudima koji ih okružuju.

Socijalno maskiranje se često spominje u kontekstu žena s PSA-om pa tako Attwood (2006) u opisima ženske kliničke slike PSA-a navodi kako žene pažljivo promatraju i pokušavaju imitirati ponašanje neke socijalno vješte osobe. U istraživanju Bargiela i sur. (2016), žene s PSA-om priopćavaju kako su upotrebljavale različite medijske izvore kako bi aktivno učile kako se socijalno maskirati. Izjavile su: "Likovi su imali ponašanja koja su bila prikladna za određene situacije, tako sam znala, ako želim nešto, moram se ponašati na određeni način." (str. 7)

Jedna žena učila je fraze i izraze lica iz znanstveno-fantastične literature kako bi se nosila s neugodnim situacijama.

"Kada su me u školi zadirkivali, postojala je knjiga Ellen Montgomery u kojoj bi lik Emily, kada bi ju netko zadirkivao... samo bi 
Stošić, J., Begić, M., Soldan, M., Djevojčice i žene s poremećajem iz spektra autizma, Klinička psihologija 13 (2020), 1-2, 95-106

ih pogledala, i zbog njezinog izraza lica nasilnici bi samo otišli." (str.7)

I u drugim istraživanjima žene s PSA-om izjavljuju o sličnim ponašanjima tijekom djetinjstva (Kalafarski, 2010; Lai i sur., 2011). U istraživanju Lai i sur. (2011), žene su postigle više opće rezultate socijalnog maskiranja od muškaraca sa PSA-om, ali uz postojanje visoke varijabilnosti unutar obje grupe.

Iako brojna istraživanja pokušavaju istražiti specifične osobitosti žena s PSA-om koje im omogućuju bolju mogućnost socijalnog maskiranja od muškaraca s PSA-om, još uvijek nema zaključnih dokaza o tome. Primjerice, Lehnhardt i sur. (2015) pretpostavljaju da je u podlozi boljeg socijalnog maskiranja kod žena veća brzina obrade informacija te bolje izvršne funkcije, što potvrđuju i Lai i sur. (2016) i tome pridodaju bolje razvijenu vještinu uočavanja podražaja iz okoline.

Istraživanje Lai i sur. (2016) također upućuje na to da kod muškaraca i žena s PSA-om socijalno maskiranje nije značajno povezano s dobi i općim intelektualnim sposobnostima. Ono je vjerojatno pobliže povezano upravo sa specifičnim obiljě̌jima kognitivnih sposobnosti, osobnosti pojedine osobe te motivacijskim ili kontekstualnim čimbenicima. Koriste ga žene i muškarci s PSA-om, a njihova individualna iskustva značajno variraju (Hull i sur., 2017).

Neke žene su izjavile da je baš socijalno maskiranje razlog za njihovu kasniju dijagnozu (Hull i sur., 2017). Primjerice, na školskom igralištu djevojčice tipičnog razvoja imaju različitu igru od dječaka tipičnog razvoja. Fluidnost ženske socijalne grupe stvara savršenu pozadinu za socijalno maskiranje djevojčica s PSA-om koje se nalaze u njihovoj blizini (Dean i sur., 2016). Ako se tu skupinu djevojčica promatra izdaleka, teško je uočiti njihove razlike. Upravo zbog povratnih informacija o normama unutar socijalne grupe, djevojčice s PSAom uče koje je očekivano ponašanje koje bi trebale imati kako bi pripale toj grupi te ga pokušavaju imitirati i maskirati svoje teškoće (Kreiser i White, 2013; Dean i sur., 2016). Uključivanje u istospolna prijateljstva i modeliranje ponašanja osoba istog spola služe za jačanje razgovornih i empatizirajućih sposobnosti kod djevojčica s PSA-om (Kreiser i White, 2013).

U odrasloj dobi, žene se mogu socijalno maskirati na način da percipiraju samo ekstremne karakteristike ponašanja neurotipičnih žena, pa se tako i one mogu ponašati i odijevati naglašavajući upravo najuočljivije karakteristike osoba svoga spola (Kreiser i White, 2013).

Većina muškaraca i žena izvještava i o negativnim posljedicama povezanim sa socijalnim maskiranjem (Tierney, Burns i Kilbey, 2016; Hull i sur., 2017). Osobe mogu osjećati kako gube vlastiti identitet, nisu dosljedne sebi te lažu ljudima oko sebe (Hull i sur., 2017). Djevojčice mogu biti pod stresom i povećanim rizikom za pojavu internaliziranih problema (anksioznosti, depresije) zbog ponovljenog iskustva negativnih socijalnih reakcija bez obzira na to koliko se trude ponašati "tipično", jer zbog svojih socijalnih teškoća ipak griješe u određenim socijalnim situacijama (Kreiser i White, 2013).

\section{Ograničeni, repetitivni i stereotipni obrasci ponašanja interesa $\mathrm{i}$ aktivnosti}

Drugi glavni kriterij za dijagnosticiranje poremećaja iz spektra autizma je i prisutnost ograničenih, repetitivnih i stereotipnih obrazaca ponašanja, interesa i aktivnosti (APA, 2013). Čini se da i na tom području postoje razlike između muškaraca i žena s autizmom.

Naime, istraživanja su pokazala da djevojčice i žene s visokofunkcionirajućim PSA- 
om imaju manje neuobičajenih repetitivnih ponašanja od muškaraca s PSA-om (Lai i sur. 2011; Kreiser i White, 2013; Duvekot i sur., 2016). Nadalje, manje su zaokupljene dijelovima predmeta te imaju manje rituala i rutina (Nicholas i sur., 2008; Mandy i sur., 2012; Solomon, Meghan, Taylor, Hinshaw i Carter, 2012). S druge strane, imaju značajno više senzoričkih poteškoća (Lai i sur., 2011).

Za razliku od dječaka, djevojčice s PSAom imaju interese slične svojim vršnjakinjama tipičnog razvoja (npr. životinje, slikanje, umjetnost, romani znanstvene fantastike, lutke). Specifičnost interesa djevojčica s PSA-om jest da su intenzivniji, da ih detaljno istražuju i provode više vremena baveći se njima od svojih tipičnih vršnjakinja (Duvekot i sur., 2016). Igra dječaka s PSA-om je neobično formalna i često uključuje sustavno slaganje igračaka po određenim, njima jasnim pravilima (Mandy i sur., 2012). Djevojčice s PSA-om češće su uključene u simboličku igru karakterističnu za djevojčice tipičnog razvoja (Kopp i Gillberg, 1992; Winter-Messiers, 2007; Knickmeyer, Wheelwright i Baron-Cohen, 2008; Kreiser i White 2013), no njihova igra nije usmjerena na interakciju s vršnjacima (Attwood, 2006).

\section{Kognitivne karakteristike}

Teorija uma i izvršne funkcije opsežno su istraživani konstrukti u osoba s poremećajem iz spektra autizma (za preglede vidi Šimleša, 2011; Demetriou, DeMayo i Guastella, 2019). Oni su ujedno i najčešće korištene dimenzije u okviru kognitivnih modela u objašnjavanju poremećaja iz spektra autizma. Izvršne funkcije obuhvaćaju niz povezanih procesa: planiranje, vremensku organizaciju ponašanja, anticipaciju cilja, započinjanje aktivnosti, nadgledanje aktivnosti, sposobnost inhibiranja ili odgađanja odgovora, evaluaciju odgovora, kognitivnu fleksibilnost potreb- nih za ponašanje usmjereno prema nekom cilju (Šimleša, 2011). U okviru manjeg broja istraživanja, istraživane su spolne razlike u izvršnim funkcijama u osoba s poremećajem iz spektra autizma. Neka od tih istraživanja su pokazala da su žene uspješnije od muškaraca s PSA-om i to u zadacima koji se odnose na kognitivnu fleksibilnost, praćenje više koncepata i planiranje unaprijed (Bölte, Duketis, Poustka, Holtmann, 2011; Lehnhardt i sur., 2015). Međutim, autori Kiep i Spek (2016) nisu pronašli razliku između muškaraca i žena u području izvršnih funkcija, što tumače činjenicom da su sudionici istraživanja imali kvocijent inteligencije koji spada u viši prosjek. U okviru nekih istraživanja utvrđeno je da žene imaju veću brzinu obrade informacija (Koyama i sur., 2009; Lehnhardt i sur., 2015), te više bodova na zadacima kodiranja i pretraživanja simbola (Koyama i sur., 2009). Muškarci s PSA-om su uspješniji u rješavanju zadataka koji zahtijevaju pažnju usmjerenu na detalje i vizualno planiranje (Nydén, Hjelmquist i Gillberg, 2000; Koyama i sur., 2009). Osim toga, bolji su od žena na zadacima koji uključuju radnu memoriju (Kiep i Spek, 2016) te imaju znatno veću bazu činjeničnih informacija (Mandy i sur., 2012). Važno je te nalaze istraživanja interpretirati s oprezom, s obzirom na to da većina istraživanja nije uključivala i uzorak neurotipičnih žena i muškaraca. Iz tog razloga trenutačno nije moguće odgovoriti na pitanje koje od tih razlika proizlaze iz općenitih razlika između muškaraca i žena i utječe li postojanje PSA-a različito na izvršne funkcije žena i muškaraca.

Teorija uma je sposobnost razumijevanja i pripisivanja mentalnih stanja (želja, uvjerenja, misli, osjećaja) sebi i drugima (Baron-Cohen, 2000). Uz nju je usko vezan i koncept empatiziranja i sistematiziranja. Empatiziranje omogućava da pridajemo smisao ponašanju druge osobe, predvidimo što bi sljedeće mogla učiniti i kako se osjeća. Sistematiziranje, s druge 
Stošić, J., Begić, M., Soldan, M., Djevojčice i žene s poremećajem iz spektra autizma, Klinička psihologija 13 (2020), 1-2, 95-106

strane, predstavlja potrebu analize i stvaranja sustava (Baron-Cohen, Knickmeyer, Belmonte , 2005). Čini se da u ovoj kognitivnoj domeni ne postoje razlike između muškaraca i žena s PSA-om. Dosadašnja istraživanja upućuju na to da muškarci i žene sa PSA-om imaju slične teškoće na testovima teorije uma te postižu niže rezultate od prosječnih na testovima empatiziranja i više prosječne rezultate na testovima sistematiziranja (Lai i sur., 2011; Kok, Groen, Becke, Fuermaier i Tucha, 2016).

\section{Problemi mentalnog zdravlja}

Mnoga istraživanja pokazuju kako se kod visokofunkcionirajućih osoba s PSA-om često pojavljuju pridružene teškoće mentalnog zdravlja te kako kod njih postoji viša razina komorbiditeta s mentalnim bolestima u usporedbi s tipičnom populacijom (Leyfer i sur., 2006; de Bruin, Ferdinand, Meester, de Nijs i Verheij, 2007; Joshi i sur., 2013). Najčešće spominjani su depresija, anksioznost, ADHD i poremećaji u ponašanju.

Istraživanja su pokazala da 30 do $70 \%$ osoba s Aspergerovim sindromom razvija neki oblik depresije tijekom života (Lugnegärd, Hallerbäck i Gillberg, 2011; Joshi i sur., 2013; Lai i sur., 2011). A osim depresije, istraživanja su pokazala i veliki rizik za razvijanje poremećaja anksioznosti (Lugnegärd i sur., 2011; Sukhodolsky i sur., 2008; Joshi i sur., 2013) Pokazalo se kako više razine anksioznosti koreliraju s višim IQ-om, boljom funkcionalnom upotrebom jezika, većom razinom stereotipnih ponašanja te većim teškoćama u socijalnom reciprocitetu (Sukhodolsky i sur., 2008).

U usporedbi s dječacima, djevojčice imaju više emocionalnih teškoća i internaliziranih problema kao što su anksioznost, depresija i somatski simptomi te nižu razinu eksternaliziranih problema (Mandy i sur., 2012; Kreiser i White, 2013). U istraživanju Mandy i sur. (2012) podupire se ideja da su spolne razlike između muškaraca i žena slične spolnim razlikama opće populacije što se tiče mentalnog zdravlja.

Neki autori pretpostavljaju da je socijalno maskiranje povezano sa simptomima depresije i anksioznosti kod ženskih osoba mlađe dobi, jer u svojem istraživanju na odraslim ispitanicima nisu pronašli te povezanosti. No naglašavaju da je socijalno maskiranje vjerojatno postalo sastavni dio ponašanja tih osoba, pa im stoga izaziva manje teškoća (Lai i sur., 2016). Suprotno tome, neka druga istraživanja, klinička promatranja i same izjave odraslih osoba upućuju na to da socijalno maskiranje i u odrasloj dobi utječe na razinu stresa, izaziva simptome anksioznosti i depresije te može biti izuzetno iscrpljujuće (Attwood, 2006; Hull i sur., 2017).

Osim navedenog, za ženske osobe s PSAom karakterističan je visoki komorbiditet $s$ anoreksijom nervosom (Gillberg i Rastam, 1992; Zucker i sur. 2007; Oldershaw, Treasure, Hambrook, Tchanturia i Schmidt, 2011), a spominje se i komorbiditet sa teškoćama učenja (Kreiser i White, 2013) te problemi sa spavanjem (Hartley i Sikora, 2009).

Unatoč postojećim istraživanjima, u praksi se pojavljuje nedostatak povezanosti između stručnjaka koji se bave PSA-om i mentalnim bolestima, te često dijagnoza PSA-a može maskirati dijagnozu mentalnih bolesti ili obrnuto. Upravo zbog toga postoji velika opasnost od tretmana i intervencija koji neće biti prilagođeni individualnim potrebama pojedine osobe (Joshi i sur., 2013)

\section{ZAKLJUČAK}

Unatoč njihovoj raznolikosti i ograničenjima s obzirom na broj i karakteristike sudionica te korištenu metodologiju, dosadašnja istraži- 
vanja upućuju na zaključak da kod djevojčica i žena poremećaj iz spektra autizma može biti izražen na drugačiji način nego kod dječaka i muškaraca. Maskiranje teškoća u socijalnoj komunikaciji, tipični interesi i manje prisutna ograničena i repetitivna ponašanja mogu dovesti do toga da PSA ne bude na vrijeme uočen. Također, ključni stručnjaci u postupku probira, dijagnostike i intervencije mogu biti više umjereni na "mušku" prezentaciju simptoma i neuobičajenosti u ponašanju tipičnih za muškarce s autizmom. Nadalje treba uzeti u obzir i teškoće u mentalnom zdravlju koje, ako se dijagnosticiraju, mogu zamagliti poremećaj iz spektra autizma koji je u njihovoj podlozi. Sve to može dovesti do toga da poremećaj ne bude na vrijeme prepoznat i dijagnosticiran te da izostane potrebna podrška.

Postavlja se pitanje jesu li postojeći mjerni instrumenti valjani za postavljanje dijagnoze kod djevojčica i žena. DSM-5 kriteriji za poremećaj iz spektra autizma uključuju različitosti u socijalnoj komunikaciji te prisutnost ograničenih i repetitivnih obrazaca ponašanja, interesa i aktivnosti koji također uključuju prisutnost senzornih teškoća. U kliničkoj i istraživačkoj praksi, mjerni instrumenti koji se smatraju zlatnim standardom su Dijagnostički protokol za procjenu poremećaja iz spektra autizma - ADOS (Autism Diagnostic Observation Schedule) (Gotham, Risi Pickles i Lord, 2007) i Dijagnostički intervju za poremećaj iz spektra autizma - ADI-R (Autism Diagnostic Intervju - Revised) (Kylie, Tonge i Deborah, 2008). Međutim, postavlja se pitanje, je li valjano koristiti baš te instrumente u procjeni za žene s autizmom. U istraživanju Lai i sur. (2011) u koje su bile uključene odrasle žene i muškarci s dijagnozom poremećajem iz spektra autizma $(\mathrm{N}=93)$ pokazalo se da je samo $20 \%$ žena postiglo rezultate koji odgovaraju ADOS kriterijima za autizam unatoč tome što su im dijagnozu postavili iskusni kliničari i što su zadovoljili kriterije za poremećaj iz spektra autizma na ADI-R intervjuu. U tom istraživanju korišten je Modul 4 ADOS procjene. U prvotnoj psihometrijskoj studiji Modula 4 samo su 5 od 30 sudionika bile žene (Lord i sur., 2000), dok u studiji Bastiaansena i suradnika (2011) u kojoj se ispituje Modul 4 u procjeni poremećaja iz spektra autizma kod odraslih osoba nije bilo ni jedne žene. $U$ istom istraživanju Lai i sur. (2016) žene su bile jednako loše na testu mentaliziranja te su u okviru samoprocjene izvještavali o čak i više karakteristika autizma nego muškarci. Sve navedeno upućuje na zaključak da žene mogu imati ponašanja i kognitivne karakteristike koje u potpunosti odgovaraju dijagnozi poremećaja iz spektra autizma, no da je moguće da ih najraširenijim dijagnostičkim instrumentom, ADOS-om, ne možemo prepoznati.

Nužno je provesti daljnja istraživanja koja će nam dati dodatni uvid u to na koje sve načine autizam može biti izražen kod žena. Kvantitativna istraživanja trebaju biti upotpunjena kvalitativnim s fokusom na iskustva djevojčica i žena, te je također nužno provesti istraživanja populacije uz korištenje aktivnih metoda. $\mathrm{Na}$ taj će se način moći razviti bolji načini prepoznavanja i diferencijalne dijagnostike, ali i razviti intervencije primjerenije potrebama žena s autizmom.

\section{LITERATURA}

Autism Europe (2016). Acceptable Language. Preuzeto sa https://www.autismeurope.org/aboutautism/acceptable-language/

American Psychiatric Association. (2013). Diagnostic and statistical manual of mental disorders (5th ed.). Arlington, VA: American Psychiatric Publishing.

Attwood, T. (2006). Asperger's and girls. London: Jessica Kingsley Publications.

Baio i sur. (2018). Prevalence of Autism Spectrum Disorder Among Children Aged 8 Years - Au- 
Stošić, J., Begić, M., Soldan, M., Djevojčice i žene s poremećajem iz spektra autizma, Klinička psihologija 13 (2020), 1-2, 95-106

tism and Developmental Disabilities Monitoring Network, 11 Sites, United States, 2014. MMWR Surveillance Summary, 67(6), 1-23.

Bargiela, S., Steward, R. i Mandy, W. (2016). The experiences of late-diagnosed women with autism spectrum conditions: An investigation of the female autism phenotype. Journal of Autism and Developmental Disorders, 46(10), 3281-3294.

Baron-Cohen, S. (2000). Theory of mind and autism: A review. International Review of Research in Mental Retardation, 23, 169-184.

Baron-Cohen, S., Knickmeyer, R. C. i Belmonte, M. K. (2005). Sex differences in the brain: Implications for explaining autism. Science, 310(5749), 819-823.

Bastiaansen, J. A., Meffert, H., Hein, S., Huizinga, P., Ketelaars, C., Pijnenborg, M., Bartels, A., Minderaa, R., Keysers, C. i de Bildt, A. (2011). Diagnosing autism spectrum disorders in adults: The use of Autism Diagnostic Observation Schedule (ADOS) module 4. Journal of Autism and Developmental Disorders, 41(9), 1256-1266.

Begeer, S., Mandell, D., Wijnker-Holmes, B., Vanderbosch, S., Rem, D., Stekelenburg, F. i Koot, H. M. (2013). Sex differences in the timing of identification among children and adults with autism spectrum disorders. Journal of Autism and Developmental Disorders, 43(5), 11511156.

Bölte, S., Duketis, E., Poustka, F. i Holtmann, M. (2011). Sex differences in cognitive domains and their clinical correlates in higher-functioning autism spectrum disorders. Autism, 15(4), 497-511.

Cepanec, M., Šimleša, S. i Stošić, J. (2015). Rana dijagnostika poremećaja iz autističnog spektrateorija istraživanja i praksa. Klinička psihologija, 8(2), 203-224.

Constantino, J. N. i Todd, R. D. (2003). Autistic traits in the general population: A twin study. Archives of General Psychiatry, 60(5), 524530.

Constantino, J. N., Zhang, Y., Frazier, T., Abbacchi, A. M. i Law, P. (2010). Sibling recurrence and the genetic epidemiology of autism. American Journal of Psychiatry, 167(11), 1349-1356.
Dean., M., Harwood, R. i Kasari, C. (2016). The art of camouflage: Gender differences in the social behaviors of girls and boys with autism spectrum disorder. Autism, 21(6), 678-689.

De Bruin, E. I., Ferdinand, R. F., Meester, S., de Nijs, P. F. i Verheij, F. (2007). High rates of psychiatric co-morbidity in PDD-NOS. Journal of Autism and Developmental Disorders, 37(5), 877-886.

Demetriou, E. A., DeMayo, M. M. i Guastella, A. J. (2019). Executive function in autism spectrum disorder: History, theoretical models, empirical findings, and pontential as an endophenotype. Frontiers in Psychiatry, 10, 753.

Duvekot, J., van der Ende, J., Verhulst, F. C., Slapendel, G., van Daalen, E., Maras, A. i Greaves-Lord, K. (2016). Factors influencing the probability of a diagnosis of autism spectrum disorder in girls versus boys. Autism, 21(6), 646-658.

Fombonne, E., Du Mazaubrun, C., Cans, C. i Grandjean, H. (1997). Autism and associated medical disorders in a French epidemiological survey. Journal of American Academy of Child \& Adolescent Psychiatry, 36(11), 1561-1569.

Fombonne, E. (2003). Epidemiological surveys of autism and other pervasive developmental disorders: An update. Journal of Autism and Developmental Disorders, 33(4), 365-382.

Fombonne, E. (2005). The changing epidemiology of autism. Journal of Applied Research in Intellectual Disabilities, 18(4), 281-294.

Fombonne, E. (2009). Epidemiology of pervasive developmental disorders. Pediatric Research, 65(6), 591-598.

Giarelli, E., Wiggins, L. D., Rice, C. E., Levy, S. E., Kirby, R. S., Pinto-Martin, J. i Mandell, D. (2010). Sex differences in the evaluation and diagnosis of autism spectrum disorders among children. Disability and Health Journal, 3(2), 107-116.

Gillberg, C. i Rastam, M. (1992). Do some cases of anorexia nervosa reflect underlying autisticlike conditions? Behavioural Neurology, 5(1), 27-32.

Goodwin, M. H. (2006). The hidden life of girls: Games of stance, status, and exclusion. Malden, MA: Blackwell. 
Gotham, K., Risi, S., Pickles, A. i Lord, C. (2007). The Autism Diagnostic Observation Schedule: Revised algorithms for improved diagnostic validity. Journal of Autism and Developmental Disorders, 37(4), 613-627.

Hartley, S. i Sikora, D. M. (2009). Sex differences in autism spectrum disorder: An examination of developmental functioning, autistic symptoms and coexisting behavior problems in toddlers. Journal of Autism and Developmental Disorders, 39(12), 1715-1722.

Holtmann, M., Bölte, S. i Poustka, F. (2007). Autism spectrum disorders: Sex differences in autistic behaviour domains and coexisting psychopathology. Developmental Medicine \& Child Neurology, 49(5), 361-366.

Hull, L., Petrides, K. V., Carrie, A., Smith, P., Baron-Cohen, S., Lai, M. -C. i Mandy, W. (2017). "Putting on my best normal": Social camouflaging in adults with autism spectrum conditions. Journal of Autism and Developmental Disorders, 47(8), 2519-2534.

Icasiano, F., Hewson, P. H., Machet, P., Cooper, C. i Marshall, A. (2004). Childhood autism spectrum disorder in the Barwon region: A community based study. Journal of Paediatrics and Child Health, 40(12), 696-701.

Joshi, G., Wozniak, J., Petty, C., Martelon, M. K., Fried, R., Bolfek, A., Kotte, A., Stevens, J., Furtak, S. L., Bourgeois, M., Caruos, J., Caron, A. i Biederman, J. (2013). Psychiatric comorbidity and functioning in a clinically referred population of adults with autism spectrum disorders: A comparative study. Journal of Autism and Developmental Disorders, 43(6), 1314-1325.

Kalafarski, E. G. (2010). Gender identity development in individuals with autism: A project based upon an independent investigation (Master Thesis). Smith College, Northampton, MA.

Ketelaars, M. P., Velt, A. I., Mol, A., Swaab, H., Bodrij, F. i van Rijn, S. (2017). Social attention and autism symptoms in high functioning women with autism spectrum disorders. Research in Developmental Disabilities, 64, 78-86.

Kiep, M. i Spek, A. A. (2016). Executive functioning in men and women with an autism spectrum disorder. Autism Research, 10(5), 940-948.
Knickmeyer, R. C., Wheelwright, S. i Baron-Cohen, S. (2008). Sex-typical play: Masculinization/defeminization in girls with an autism spectrum condition. Journal of Autism and Developmental Disorders, 38(6), 1028-1035.

Kok, F. M., Groen, Y., Becke, M., Fuermaier, A. B. M. i Tucha O. (2016). Self-reported empathy in adult women with autism spectrum disorders-A systematic mini review. PLoS ONE, 11(3).

Kopp, S. i Gillberg, C. (1992). Girls with social deficits and learning problems: Autism, atypical Asperger syndrome or a variant of these conditions. European Child and Adolescent Psychiatry, 1(2), 89-99.

Koyama, T., Kamio, Y., Inada, N. i Kurita, H. (2009). Sex differences in WISC-III profiles of children with high-functioning pervasive developmental disorders. Journal of Autism and Developmental Disorders, 39(1), 135-141.

Kreiser, N. L. i White, S. W. (2013). ASD in females: Are we overstating the gender difference in diagnosis? Clinical Child and Family Psychology Review, 17(1), 67-84.

Kylie, M. G., Tonge, B. i Deborah, J. S. (2008). Using the Autism Diagnostic Interview-Revised and the Autism Diagnostic Observation Schedule with young children with developmental delay: Evaluating diagnostic validity. Journal of Autism and Developmental Disorders, 38(4), 657-667.

Lai, M. -C., Lombardo, M. V., Pasco, G., Ruigrok, A. N. V., Wheelwright, S. J., Sadek, S. A., Chakrabarti, B., MCR AIMS Consortium i BaronCohen, S. (2011). A behavioral comparison of male and female adults with high functioning autism spectrum conditions. PLoS ONE, 6(6).

Lai, M.-C., Lombardo, M. V., Suckling, J., Ruigrok, A. N., Chakrabarti, B., Ecker, C., Deoni, S. C. L., Craig, M. C., Murphy, D. G. M., Bullmore, E. T., MCR AIMS Consortium i Baron-Cohen, S. (2013). Biological sex affects the neurobiology of autism. Brain: A Journal of Neurology, 136(9), 2799-2815.

Lai, M. -C., Lombardo, M. V., Ruigrok, A. N., Chakrabarti, B., Auyeung, B., Szatmari, P., Happé, F., Baron-Cohen, S. i MRC AIMS Consortium (2016). Quantifying and exploring camouflaging in men and women with autism. Autism, 2(6), 690-702. 
Stošić, J., Begić, M., Soldan, M., Djevojčice i žene s poremećajem iz spektra autizma, Klinička psihologija 13 (2020), 1-2, 95-106

Larson, R. i Richards, M. H. (1989). Introduction: The changing life space of early adolescence. Journal of Youth and Adolescence, 18(6), 501509.

Lehnhardt, F. G., Falter, C. M., Gawronski, A., Pfeiffer, K., Tepest, R., Franklin, J. i Vogeley, K. (2015). Sex-related cognitive profile in autism spectrum disorders diagnosed late in life: Implications for the female autistic phenotype. Journal of Autism and Developmental Disorders, 46(1), 139-154.

Leyfer, O. T., Folstein, S. E., Bacalman, S., Davis, N. O., Dinh, E., Morgan, J., Tager-Flusberg, H. i Lainhart, J. E. (2006). Comorbid psychiatric disorders in children with autism: Interview development and rates of disorders. Journal of Autism and Developmental Disorders, 36(7), 849-861.

Loomes, R., Hull, L. i Mandy, W. P. L. (2017). What is the male-to-female ratio in autism spectrum disorder? A systematic review and metaanalysis. Journal of the American Academy of Child \& Adolescence Psychiatry, 56(6), 466474.

Lord, C., Risi, S., Lambrecht, L., Cook, E. H., Leventhal, B. L., DiLavore, P., Pickles, A. i Rutter, M. (2000). The Autism Diagnostic Observation Schedule- Generic: A standard measure of social and communication deficits associated with the spectrum of autism. Journal of Autism and Developmental Disorders, 30(3), 205-223.

Lugnegärd, T., Hallerbäck, M. U. i Gillberg, C. (2011). Psychiatric comorbidity in young adults with a clinical diagnosis of Asperger syndrome. Research in Developmental Disabilities, 32(5), 1910-1917.

Maccoby, E. E. (1999). The two sexes: Growing up apart coming together. Cambridge, MA: First Harvard University Press.

Mandy, W., Chilvers, R., Chowdhury, U., Salter, G., Seigal, A. i Skuse, D. (2012). Sex differences in autism spectrum disorder. Journal of Autism and Developmental Disorders, 42(7), 13041313.

Nicholas, J. S., Charles, J. M., Carpenter, L. A., King, L. B., Jenner, W. i Spratt, E. G. (2008). Prevalence and characteristics of children with autism-spectrum disorders. Annals of Epidemiology, 18(2), 130-136.

Nydén, A., Hjelmquist, E. i Gillberg, C. (2000). Autism spectrum and attention-deficit disor- ders in girls: Some neuropsychological aspects. European Child \& Adolescent Psychiatry, 9(3), 180-185.

Oldershaw, A., Treasure, J., Hambrook, D., Tchanturia, K. i Schmidt, U. (2011). Is anorexia nervosa a version of autism spectrum disorders? European Eating Disorders Review: The Journal of Eating Disorders Association, 19(6), 462-474.

Raffaelli, M. i Duckett, E. (1989). "We were just talking...": Conversations in early adolescence. Journal of Youth and Adolescence, 18(6), 567-582.

Russell, G., Steer, C. i Golding, J. (2011). Social and demographic factors that influence the diagnosis of autistic spectrum disorders. Social Psychiatry and Psychiatric Epidemiology, 46(12), 1283-1293.

Solomon, M., Meghan, M., Taylor, S. L., Hinshaw, S. P. i Carter, C. S. (2012). Autism symptoms and internalizing psychopatology in girls and boys with autism spectrum disorders. Journal of Autism and Developmental Disorders, 42(1), 48-59.

Sukhodolsky, D. G., Scahill, L., Gadow, K. D., Arnold, L. E., Aman, M. G., McDougle, C. J., McCracken, J., Tierney, E., Williams White, S., Lecevalier, L. i Vitiello, B. (2008). Parent-rated anxiety symptoms in children with pervasive developmental disorders: Frequency and association with core autism symptoms and cognitive functioning. Journal of Abnormal Child Psychology, 36(1), 117-128.

Šimleša, S. (2011). Izvršne funkcije i teorija uma kod osoba s poremećajem iz autističnog spektra. Psihologijske teme, 20(1), 91-113.

Tierney, S., Burns, J. i Kilbey, E. (2016). Looking behind the mask: Social coping strategies of girls on the autistic spectrum. Research in Autism Spectrum Disorders, 23, 73-83.

Winter-Messiers, M. A. (2007). From tarantulas to toilet brushes: Understanding the special interest areas of children and youth with Asperger syndrome. Remedial and Special Education, 28(3), 140-152.

Zucker, N. L., Losh, M., Bulik, C. M., LaBar, K. S., Piven, J. i Pelphrey, K. (2007). Anorexia nervosa and autism spectrum disorders: Guided investigation of social cognitive endophenotypes. Psychological Bulletin, 133(6), 9761006. 
Korespondencija: Jasmina Stošić

Edukacijsko-rehabilitacijski fakultet Sveučilišta u Zagrebu,

Borongajska 83 f, 10000 Zagreb

jasmina.stosic@erf.unizg.hr
Primljeno:

Prihvaćeno:

Online:

Print:
09. 02. 2020.

24. 09. 2020.

30. 10. 2020

27. 11. 2020.

\section{Girls and Women with Autism Spectrum Disorder}

Summary: Autism spectrum disorder includes diversities and difficulties in social communication and in behaviour, interests and activities. It was considered to be a "male" disorder, but research has shown that the number of women with ASD is underestimated, that they receive their diagnosis later in life and that they have to express more difficulties to get it. Characteristics of girls and women with ASD and differences between men and women with ASD will be presented in this paper. Latest research has shown that girls and women express less difficulties in social communication and use social camouflaging more than males. They also have typical interests more often and express less limited and repetitive behaviours. Future research should include prevalence, experiences of women and girls with ASD and diversities in their expression in ASD. That could lead to earlier diagnosis and enable development of support and services tailored to their specific needs.

Key words: autism, women with ASD, social camouflaging 